\title{
Lung exposure during simultaneous myocardial revascularization and lung surgery through median sternotomy
}

\author{
Dariusz Jagielak ${ }^{1}$, Radoslaw Kozaryn ${ }^{1}$, Rafal Pawlaczyk ${ }^{1}$, Piotr Siondalski ${ }^{1}$, Witold Rzyman ${ }^{2}$, Jan Rogowski ${ }^{1}$ \\ ${ }^{1}$ Department of Cardiac Surgery, Medical University of Gdansk, Poland \\ ${ }^{2}$ Department of Thoracic Surgery, Medical University of Gdansk, Poland
}

Kardiochirurgia i Torakochirurgia Polska 2016; 13 (4): 316-318

\begin{abstract}
Coronary artery disease is a frequent comorbidity in patients undergoing major thoracic surgery. Simultaneous operations eliminate the necessity of a second operation and, more importantly, minimize the delay in compulsory postoperative oncological therapy. We describe a relaxing incision in the contralateral pericardium, which allows for simple displacement of the heart. This maneuver improves exposure of the pulmonary hilum and middle mediastinum on the side of resection. Key words: median sternotomy, off-pump surgery, lung cancer.
\end{abstract}

\section{Introduction}

The data concerning combined cardiac and pulmonary surgery through median sternotomy are scarce and remain controversial. Despite symptoms of coronary artery disease (CAD) in $10 \%$ of lung cancer patients undergoing surgery, combined operations are still uncommon [1-3]. In selected patients with concomitant severe CAD and malignant neoplasia, simultaneous off-pump myocardial revascularization and lung resection could be the optimal choice [4]. Such a technique can avoid the hemodynamic instability caused by heart disease during the pulmonary stage of the procedure, decreasing operative complications and hospital stay. Moreover, in this approach we eliminate the potential complications of extracorporeal circulation (ECC): "postperfusion syndrome", edema in the residual lung tissue and risk of dissemination of neoplastic cells [5].

Median sternotomy provides optimal exposure for the majority of cardiac procedures.

Theoretically, any anatomic pulmonary resection can be performed through this incision; however, many such resections pose significant technical challenges [6]. The main

\section{Streszczenie}

Współwystępowanie choroby niedokrwiennej serca i nowotworu płuc jest najczęstszym wskazaniem do łączonych zabiegów sercowo-płucnych. Jednoczesne operacje eliminują potrzebę dodatkowych hospitalizacji, a co za tym idzie - zmniejszają opóźnienie podania chemioterapii. W pracy opisujemy technikę operacyjną polegającą na nacięciu osierdzia, umożliwiającą przemieszczenie serca do naprzeciw położnej jamy opłucnowej podczas preparowania wnęki operowanego płuca. Manewr ten ułatwia zadowalającą ekspozycję wnęki płuca przy zachowaniu wydolnej hemodynamiki po rewaskularyzacji serca bez wykorzystania krążenia pozaustrojowego.

Słowa kluczowe: sternotomia pośrodkowa, pomostowanie aortalno-wieńcowe bez użycia krążenia pozaustrojowego, rak płuc.

limitations of a median sternotomy for pulmonary resection are difficult visualization, dissection of lower lobe arterial and venous branches and difficulty resecting lymph node stations 7, 8 and 9. Furthermore, single lung ventilation increases the challenge of pulmonary resection via median sternotomy [7]. These technical problems require stringent balancing of the risks and benefits of combined treatment and consequently have swayed many surgeons in the direction of performing staged operations instead. We suggest a solution to the aforementioned difficulties related to this particular procedure through the creation of a bilateral pleuro-pericardial window and displacement of the heart.

\section{Technique}

Classical off-pump coronary revascularization is performed first, followed by the lung resection. Median sternotomy is performed in the standard fashion. The pericardium is opened with a reversed T-shaped incision extending from the aorta to the diaphragm and drawn down the entire length of the pericardium bilaterally. When the cardiac part of the operation is completed and protamine is injected,

Address for correspondence: Radoslaw Kozaryn, Department of Cardiac Surgery, Medical University of Gdansk, 7 Debinki St, $80-211$ Gdansk, Poland, phone: +48 5834924 03, fax: +48 5834176 69, e-mail: rkozaryn@uck.gda.pl

Received: 14.07.2015, accepted: 23.11.2016. 

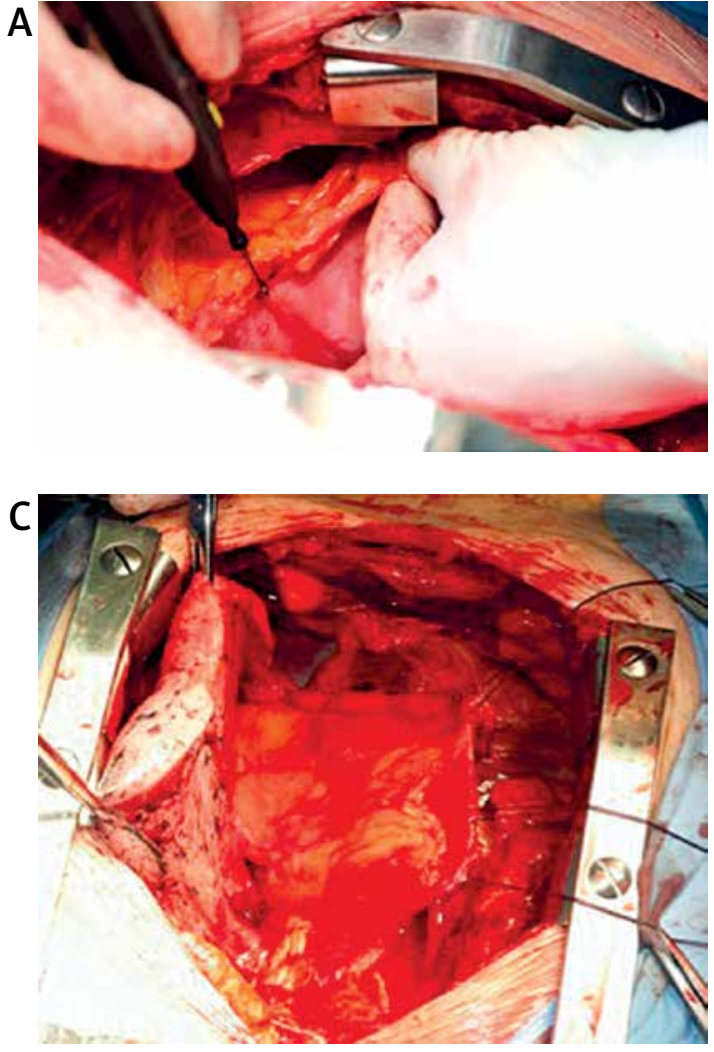
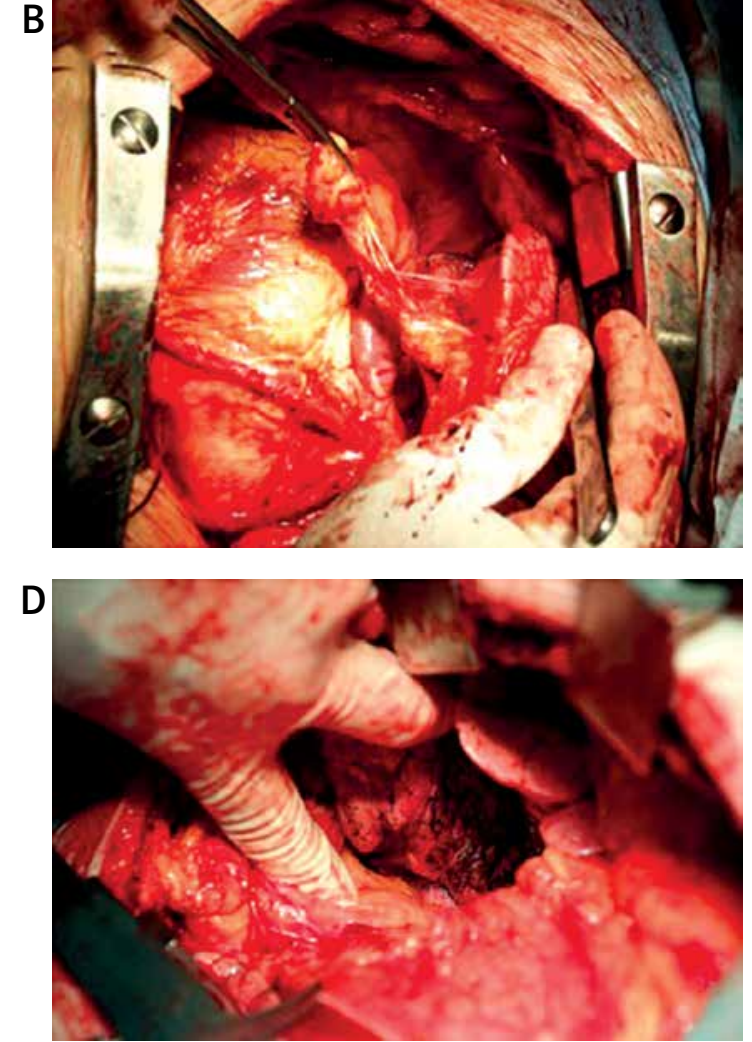

Fig. 1. A - Line of the pleural incision, B - exposure of the right hilum, C - intraoperative view of the left lung cavity - three retracting sutures pulling the pericardium away - the heart is placed inside the contralateral space - it also improves the hemodynamics, D - view of the right lower lobe

the pulmonary portion can commence with the creation of a bilateral pleuro-pericardial window. We open both pleural cavities by an incision in the contralateral pericardium posterior to the phrenic nerve. The left and right pleurae are widely opened parallel to the longitudinal incision of the pericardium. The incision of the left pleura reaches the apex of the heart, while the incision of the right pleura is extended to the diaphragm and driven down the pericardium to the inferior vena cava. In this manner, a space is created that allows for easy displacement of the heart to the pleural cavity opposite to the operated lung. Two or three traction stitches are placed on the pleuro-pericardial margin of the operated side to simplify dislocation (Fig. 1). Intrapleural placement prevents any heart compression during lung resection and therefore almost eliminates the risk of hemodynamic instability. In addition, this simple maneuver increases retraction in the pleural space in which the pulmonary pathology resides.

\section{Discussion}

We have been using this maneuver successfully during all concomitant procedures since 2001 . The most common indication for combined surgery was coexisting pulmonary malignancy and coronary artery disease. The number of supporters of concomitant heart and lung operations is steadily increasing. Arguments favoring such type of treatment are based on several medical and economic benefits.
Of critical significance is the fact that simultaneous operations eliminate the necessity of a second operation and do not defer necessary postoperative oncological therapy. Avoiding additional anesthesia, stress and postoperative pain connected with the second operation, and earlier lung resection can result in lower postoperative morbidity and mortality. Additionally, one intervention through the median sternotomy reduces pain and accelerates recovery of respiratory function in the early postoperative period. A single hospital stay is associated with reduced treatment costs. In selected patients, concomitant heart surgery and pulmonary tissue resection can be performed safely and is a feasible alternative to the two-stage approach. The bilateral pleuro-pericardial window creation and heart displacement technique gives improved surgical exposure of the heart and lung hilum and plays an important, promising role in such interventions.

\section{Disclosure}

Authors report no conflict of interest.

\section{References}

1. Schoenmakers MC, van Boven WJ, van den Bosch J, van Swieten HA. Comparison of on-pump or off-pump coronary artery revascularization with lung resection. Ann Thorac Surg 2007; 84: 504-509.

2. Ciriaco P, Carretta A, Calori G, Mazzone P, Zannini P. Lung resection for cancer in patients with coronary arterial disease: analysis of short-term results. Eur J Cardiothorac Surg 2002; 22: 35-40. 
3. Rao V, Todd TR, Weisel RD, Komeda M, Cohen G, Ikonomidis JS, Christakis GT. Results of combined pulmonary resection and cardiac operation. Ann Thorac Surg 1996; 62: 342-346.

4. Dyszkiewicz W, Jemielity MM, Piwkowski CT, Perek B, Kasprzyk M. Simultaneous lung resection for cancer and myocardial revascularization without cardiopulmonary bypass (off-pump coronary artery bypass grafting). Ann Thorac Surg 2004; 77: 1023-1027.

5. Ulicny Jr KS, Schmelzer V, Flege Jr JB, Todd JC, Mitts DL, Melvin DB, Wright CB. Concomitant cardiac and pulmonary operation: the role of cardiopulmonary bypass. Ann Thorac Surg 1992; 54: 289-295.
6. Johnson JA, Landreneau RJ, Boley TM, Haggerty SP, Hattler B, Curtis JJ, Hazelrigg SR. Should pulmonary lesions be resected at the time of open heart surgery? Am Surg 1996; 62: 300-303.

7. Toker A, Dilege S, Kalayci G. Combined left pneumonectomy and off-pump coronary artery bypass: principles of cancer surgery. Eur J Cardiothorac Surg 2002; 21: 370-371. 